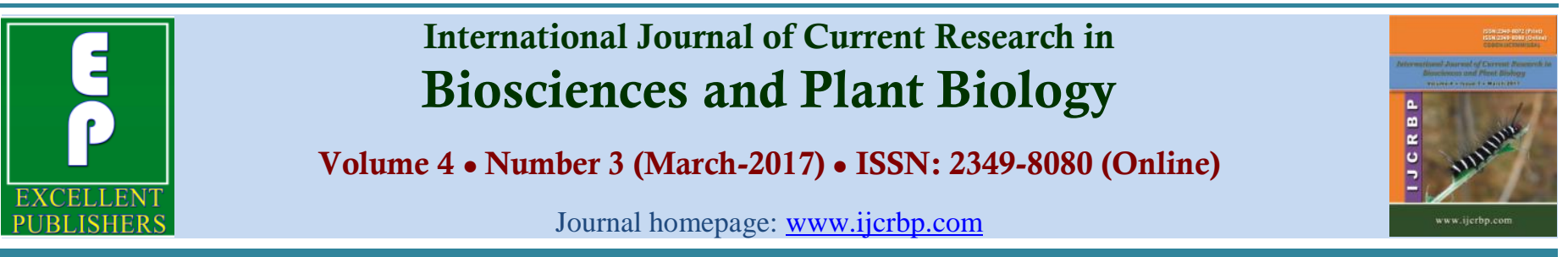

\title{
Trend of Smoking Behavior and the Social Impact on Adolescents at Makassar in Indonesia
}

\author{
Muzakkir M. Kes* \\ STIKES Nani Hasanuddin Makassar, South Sulawesi, Indonesia \\ *Corresponding author.
}

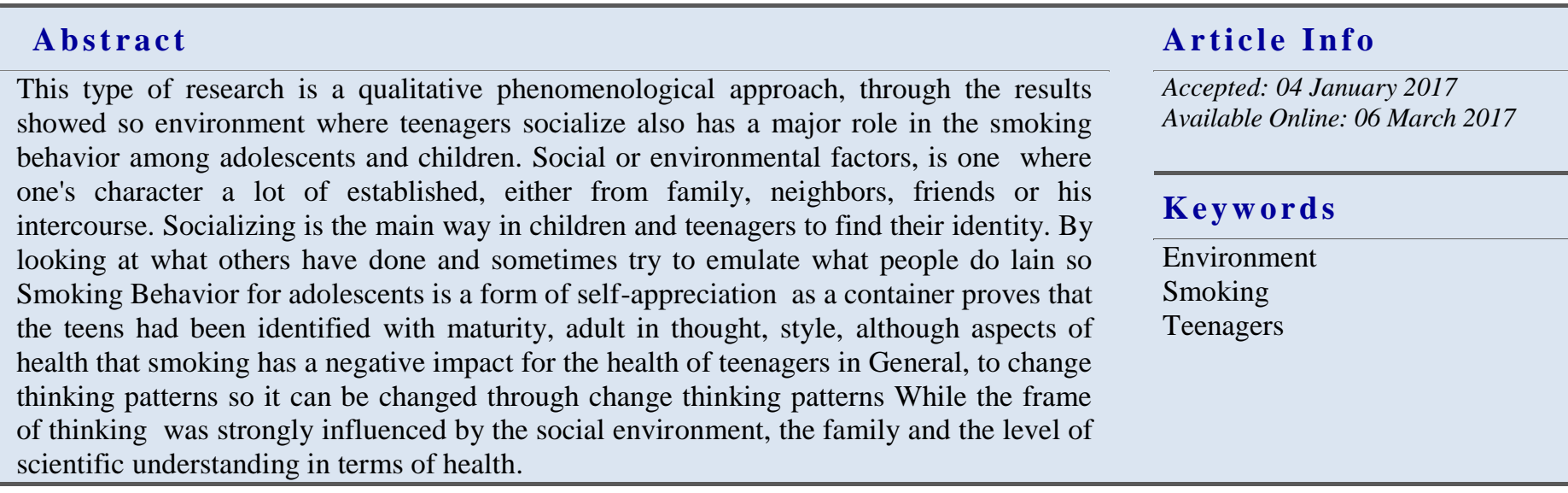

\section{Introduction}

Smoking is one of the difficult problems are solved. Moreover, it has become a matter of national, and even international. It is becoming difficult, because it relates to many factors that trigger each other, so that it is as though it has become a vicious circle. In a review in terms of health, smoking should be stopped because it causes blood vessel blockage and cancer resulting in death, therefore smoking should be stopped as a precautionary effort as early as possible. First, note that most smokers are teenagers, so that the need for early prevention that begins from the school. Smokers enjoy smoking is so real, until it is reasonably give a sense of fun and refreshing so that every day should be set aside money for smoking. Other groups, particularly adolescent males, they assume that smoking is virility is that boast, so those who don't smoke bullied thus instead. But they are aware that smoking can harm health even elicited a lot of serious illness. The issue of smoking in fact has already become a matter of national, even international. Starting from adults with small children consume cigarettes. The behavior of smoke seen from various viewpoints very detrimental, both for yourself and the surrounded. The influence of chemicals contained smoking, such as nicotine, CO (karbonmonosida) and tar can cause a variety of ailments. Views from the health side, the influence of chemicals will spur nerve center of work and nerves sympathetic dystrophy resulting in increased blood 
pressure and heart rate increases rapidly, stimulating cancer and various other diseases such as constriction of blood vessels, high blood pressure, heart, lungs and chronic bronchitis. The smoking activity performed by children who are usually done in front of other people, especially done in front of the group (Amelia, 2009).

According to Ogawa in the Triyanti (2006, p. 56), formerly the smoking behavior is referred to as a habit or addiction, but nowadays smoking, is referred to as the tobacco dependency or addiction to tobacco. Tobacco dependency itself can be defined as the behavior of tobacco use that settled, usually more than half packs of cigarettes per day, with the additional presence of distress caused by necessity of tobacco repeatedly. The smoking behavior can be also defined as the activity of the subject that deals with the behavior of smoking, measured through the intensity of the smoke, the smoking time, and smoke in daily life (Komalasari and Helmi, 2000, p. 31). While Leventhal and Cleary (1980, p. 50) States that the behavior of smoke formed through four stages, namely: preparation, initiation, stages of becoming a smoker, and the maintenance of smoking. The smoking behavior of children is the behavior of symbolizing. A symbol of maturity, strength, leadership, and the process of imitation from people around him. On the other hand, the first time consuming smoking, symptoms may happen is coughing, tongue tasted bitter, and stomach nausea. However, some of the novices ignore these feelings, it usually continues into habit, and finally to dependency, (Amelia, 2009, p. 46).

Even though everyone knows the dangers posed due to smoke, the smoking behavior never receded and seems to be a behavior that can still be tolerated by the community. This can be felt in everyday life in the home environment, Office, public transport as well as on the streets. Almost every moment can be seen and in the encounter people who are smoking. The number of smokers is ever growing every year.

This is supported by data that the number of smokers in Indonesia ranked the third highest in the world, which is about 65 million people (surya.co.id) Indonesia is also the country's largest environmental smoker ASEAN countries. It was based on data from The ASEAN Tobacco Control Report 2007. The ASEAN Tobacco Control Report Card 2007 mentions the number of smokers in the ASEAN reached 124,691 million people and Indonesia accounted for the biggest smokers, i.e. 57,563 million people or about 46.16 percent.
(Kompas.com)

Thing of concern is age start smoking every year is getting younger. When first starting to dare to smoke usually started JUNIOR HIGH and now can be found kids ELEMENTARY SCHOOL 5th grade have started many who smoke secretly. Prevalence of smokers in Indonesia is increasingly growing day and concern. The highest increase of smokers in Indonesia occurred in the Group of teens aged 15-19 years, i.e., from 7.1 per cent in 1995 to 17.3 percent in 2004, up 144 percent over the last 9 years (Kompas.com)

Smoking is still a health problem in Indonesia. The number of smokers in the world Indonesia ranks third after China and India, while the level of Southeast Asia ranks first. Indonesia also ranks the fifth largest tobacco producer in the world (WHO, 2008). Smoking is one of the biggest causes of death in the world. Smoking in adolescent age can accelerate the death of 20 to 25 years earlier in the appeal by not getting exposure to smoking (PDPI, 2011) Health Research Data Base (Riskesdas) in 2007 showed that the national prevalence of smokers in Indonesia is $29.2 \%$ and has increased at Riskesdas 2010 be $34.7 \%$. Adolescence can be a time where individuals consume cigarettes. Smet (1994) argues that the age of first smoking generally ranging between the ages of 1113 years and in general they start to smoke before the age of 18 years. The age can be categorized is included in the stretch of adolescence. Furthermore the Data reaffirms that teenagers $\mathrm{WHO}$ have a high propensity to smoke, the WHO data shows that the number of smokers from all over the world as much as $30 \%$ were adolescents (Republika, 1988).

There are many reasons which aspects influenced teenagers to smoke. It is generally based on the study of Kurt Lewin, smoking is a function of the environment and the individual. This means that, in addition to the smoking behavior resulting from environmental factors also caused by factors or personality self. Factors in adolescents can be seen from the study of adolescent. Teenagers start smoking said by Erikson (Gatchel, 1989) relating to the existence of the psychosocial aspects of the crises experienced during its development, namely a time when searching for identity. Some teens do the smoking behavior as a way of compensatory. As told by Brigham (1991) cited by Helmi, that the smoking behavior for adolescents is symbolizing behavior. Symbol of maturity, strength, leadership, and attraction towards the opposite sex. 
Smoked for most adolescents is the projection of pain behavior either psychic or physical. Although on the other hand, the first time consuming smoking felt not good. This is in line with the word Helmi said that the first time you consume cigarettes, most teens may experience symptoms of coughing, tongue tasted bitter, and stomach nausea. However, some of the novices ignore the feeling experience, it usually continues into the habit and eventually became a dependency Meeker and Klinke (in Aritonang, 1997) say that the motive of the smokers is relaxation. With smoking can reduce tension, eases concentrating, experience fun and relaxation.

\section{Formulation of the problem}

\section{What's behind the smoking behavior among adolescents at Makassar}

\section{The smoking behavior}

The behavior of smoke seen from various viewpoints very prejudicial, either for yourself or the person in Her. Seen from the individual concerned, there is some research that supports the statement. Views from the health side, the influence of chemicals contained smoking, such as nicotine, $\mathrm{CO}$ (Karbonmonoksida) and tear will spur work of the order of the central nervous and neural sympathetic dystrophy arrangement resulting in increased blood pressure and heart rate increases rapidly (Kendal \& Hammen, 1998), stimulate cancer and various other diseases such as constriction of blood vessels, high blood pressure, heart, lungs, and chronic bronchitis (Kaplan et al, 1993). For pregnant women, smoking causes premature births, low baby weight, prenatal mortality, likely born in a State of disability, and experiencing a disruption in development (Davidson \& Neale, 1990). Research result Larson dkk (in Theodore, 1994) found that olfactory acuity and tasting sensivitas smokers decreases when compared to nonsmokers. The potential negative impacts of smoking for passive smokers. The risks borne by the passive smokers more dangerous than an active smoker because of durability against dangerous substances are very low (Safarino in Cahyani, 1995). There is nothing that belies the existence of the negative effects of smoking behavior but the smoking behavior for human life is an activity that ' phenomenal '. That is, although already known negative consequences of smoking, but the number of smokers is not declining, but increased and the smoking age growing younger. The results of
Research Institutions to cope with the problem of smoking (Republika, 1998) reported that in children in Indonesia are already there who started smoking at the age of 9 years. Smet (1994) says that the age of first smoking generally ranging between the ages of 11-13 years and they generally smoke before the age of 18 years. The WHO data also increasingly expresses that the whole number of smokers in the world as much as $30 \%$ were adolescents (Republika, 1998). Almost 50\% of smokers in the United States include age adolescents (Theodore, 1994). Based on these data it can be said that the behavior of smoke began in their children and teens. As told by Brigham (1991) that the smoking behavior for adolescents is symbolizing behavior: A symbol of maturity, strength, leadership, and attraction towards the opposite sex. On the other hand, the first time consuming smoking, symptoms that might happen is coughing, tongue tasted bitter, and stomach nausea.

\section{Value system in the smoke}

Basically the smoking behavior is behavior that is learned. It means there is a party-influential party in the process of socialization. The concept of developing the first socialization of sociology and social psychology is a process of tranmisi values, belief systems, attitudes, or the actions of the previous generation the next generation (Durkin, 1995). As for the purpose of socializing this is so that the next generation has a value system that corresponds to the desired norm demands by the group, so accepted within a group. In relation to smoking behavior, basically almost no parent who wanted his son to become smokers, even society does not demand the community members to become smokers. However, in this regard are not aware, there is some agent who was the model amplifier for smokers and adolescents. Who are the agents of socialization of the smoking behavior for adolescents? With reference to the concept of tranmisi behavior, on basically can be way through the vertical and horizontal tranmisi (Berry et al, 1992).

\section{Theory of social behavior of smoking}

In the study of sociology, theory of behavior associated with smoking is a symbolic interaction theory. This theory emphasizes the study of Sociology of the interaction between individuals and in the process where the individual develops a point of view about themselves and connect with fellow individuals. Interaction is the symbolic view of life as a social process. So there is a 
socialization in it. In the process of socialization of this theory, which deals with the behavior of smoke is a theory of socialization, according to George Herbert Mead, socialization that someone can be distinguished in the following stages.

- Stage of preparation (Preparatory Stage).

This stage experienced by humans since birth, when a child prepares for.

Get to know the social world, including to gain an understanding of themselves.

- Phase mimics (Stage Play)

- Stage ready Act (Game Stage)

- The stage of acceptance of collective norms (Generalized Stage).

\section{Theoretical studies}

In this case the theory approach is used as the unit of analysis is the theory of child development which includes:

1. The Psychoanalytical theories

2. Cognitive theories

3. Theories of behavioral and Social Learning

4. Ecological theories

The reasons for the use of the above theory of the fourth because the case happened very complex and it takes some sort of approach in looking at the problems occurred. Thus the necessary theoretical studies greatly help others in providing a more detailed description of both in the psychological development, as well as the social environment surrounding self as a form of learning the values that have been accepted in the children behave.

\section{The psychoanalytical theories}

Two important psychoanalytic theory is the theory of Freud and Erikson's theory.

- Freud says personality is composed of three structures - id, ego and superego, and the thought that most children are not realized.

- Erikson developed a theory that emphasizes the psychosocial stages of development: eight trust versus mistrust; autonomy versus shame and doubt; initiative versus guilt; diligent versus versus inferiority; identity versus identity confusion; intimacy versus except; rose versus stagnates; our satisfaction versus disappointments (despair).

\section{Cognitive theories}

Two important cognitive theory is a theory of cognitive development of Piaget's theory and information processing.

- Piaget said that children beyond the four stages of cognitive development: sensorimotor, proportional, concrete operational, and formal operational.

- Information processing Theory regards how individuals process information about his world, which include: How does the information get into the mind, how information is stored and disseminated, and how information was taken back to allow us to think and solve problems.

\section{Behavioral and social learning theory}

- Behaviorism stressed that cognition is not important in understanding behavior. According to B.F. Skinner, an expert on development is well-known, behaviorists behaviors were observed, which is determined by the prize and punishment in the environment.

- Social learning theory developed by Albert Bandura and his friends, stating that the environment is an important factor that affects behavior, cognitive processes but no less important. According to the view of social learning, humans have the ability to control their own behavior.

\section{Ecological Theory}

- In ecological theory Brofenbrenner, there are five important environmental systems: mikrosistem, mesosistem, ecosystem, makrosistem

\section{Research methods}

This type of research is a qualitative phenomenological approach through standard procedures.

\section{Results and discussion}

\section{The smoking behavior in teenagers}

Troubleshooting for the smoking behavior among adolescents and children by way of early prevention, starting from the smallest neighborhood families. It can be described as follows:

1. Understand the interest that can be caused by 
smoking. The trick with invited a discussion about smoking, including his views on smoking.

2. Say no to smoking.

3. Provide a good example.

Children will usually mimic the actions of people close, so when a parent forbids his son to smoke, they should also do not consume cigarettes.

4. Smoking is not cool. Show children that smoking is not something cool things or can be proud of.

5. Understand the pressure from peers. The presence of friends who smoke can affect children. Give them the confidence to be able to socialize with their friends without smoking.

6. Handle addiction due to smoking seriously.

A lot of teenagers who believe they can quit smoking anytime they want, but the reality of nicotine can make them become addicted just as in adults. So needed serious handling, for example by way of rehabilitation.

7. Give an overview about their future.

Children tend to believe that they will not be exposed to the harms of smoking. But health problems such as cancer, heart attack and stroke are very at risk experienced by those who smoked.

8. Get involved is actively involved in the activities of prevention of smoking either at school or home environment.

Aside from the family environment, the necessary role of the media in the prevention of too early. This can be done with the minimize advertising about smoking, nor give information all people about the dangers of smoking for the health of adolescents. The Government can also play a role in the prevention of premature, with how to implement a rule that firm and clear on tobacco and smoking. With the support of all parties, then the early prevention of smoking behavior can be implemented, so that the number of teenage smokers and children can be reduced. Because teenagers and children are the next generation of the nation.

Smoke is an overt behavior where smokers of tobacco rolls Shuck. It is like writing in KBBI smoking is sucking up the roll of tobacco wrapped in paper (great dictionary of Indonesian Language (1990:746). Furthermore Poerwadarminta in Minangkabau (2007:9) defines smoking as suck cigarettes, and smoking was defined as a roll of tobacco wrapped in a palm leaf or paper. Fakhrurrozi identifying smoking as overt behavior because smoking is a behavior that appears. As the overt behavior of smoking is a behavior that can be seen smoking because when the individual performs an activity that appears to be IE suck smoke burned into the body, it is similar to the opinions of Armstrong in the Minangkabau (2007:10) smoking is sucking up tobacco smoke that burned into the body and waste air back out.

The smoking behavior influenced the feeling negative. According to Silvan Tomkins (Muta'din: 2002) many people who smoke for negative feelings in her. For example smoke when angry, anxious, restless, smoking is considered a Savior. They use smoking when feeling uncomfortable going, so avoid juice, which is not good.

The smoking behavior in teenagers is the behavior of transmisif. Research of Helmi and Komalasari (2000) obtained the conclusion that smoking behavior is behavior that is learned and transmitted through the activity of permissive behavior of peers and parents. The smoking behavior is driven by the values in adolescents. Some of the motivations behind their smoking are to gain recognition (anticipatory beliefs) to eliminate the frustrations (reliefing beliefs) and considers his actions did not violate the norms (the permission of beliefs/positive) (Joemana, 2004).

\section{Background of smoking and addiction of smoking behavior in teenagers}

There are many factors that affect a person for smoking. Hansen in Minangkabau (2008) argues that the factors that influence the smoking behavior: biological factors, factors of psiklogis, social environmental factors, demographic factors, socio-cultural factors, political factors. But at most affect the behavior of teens who smoke are:

\section{The influence of parents}

One of the findings of the teenage smoker is that young children who come from households that are not happy, where parents are not so attentive to the children and give a hard corporal punishment easier to become smokers than the younger kids that come from the environment a happy home (Baer and Corado in Atkinson, introduction to psychology, 1999:292) Found also by Helmi and Komalasari (online) that the attitude of permissive parents has a significant correlation with smoking behavior in teenagers.

\section{The influence of friends}

Various facts revealed that more and more teenagers are 
smoking the more likely it is that his friends are smokers and also vice versa. From the fact that there is a possibility of him going on, first, the teenagers affected by his friends or even friends of the teenagers affected by the teenagers themselves that finally they all became smokers. Among teen smokers there are $87 \%$ had at least one or more companions who are smokers as well as nonsmokers, teens (al. Bachri, 1991).

\section{Personality}

Projection: Teen smoking because of the curious or want to escape from physical pain or soul of free yourself from boredom. According to Hidayat, Teddy (people's Thoughts: 2007) teenagers at high risk are adolescents who have satisfied soon, less capable of postponing desire, feeling empty and easy to get bored easy, anxious, restless, and depressive. This is confirmed by the results of research from CASA (Columbian University's National Center On Addiction and Substance Abuse), teenage smokers have twice the risk of experiencing symptoms of depression than teens who don't smoke.

Sense of curiosity: Of the development of adolescent cognitions demands a sense of curiosity. Along with it social cognition on the developing adolescent, so teenagers often try doing activities that are supported by the Association.

\section{The compensation senseless confident}

A sense of lacking confidence in teenagers is manifested in various ways, either with a positive or negative way. A positive way to build confidence is to create positive self definition, fight for a positive desire, resolve the problem positively, have a positive decision. While a negative way to build up the confidence that is difficult to accept the reality of the self (first accept the shortcomings themselves) and look down on the ability of self-but on the other hand put up no realistic expectations towards yourself. Negative acts tend to do that is with smoking, so by using these substances teens are more likely to feel confident (Jacinta, 2002).

\section{Factors Cause the smoking Behavior}

The smoking is a behavior that is harmful to health, but there are still many people who do it. Even people start smoking when they were still teenagers. Origin, the cigarette people feel uncomfortable, for example head reel, dry mouth and smell. But eventually if forwarded many times and conditioned so smokers would feel delicious and tasty. After it is hooked, addicted, and are subject to, either physical or psychic. There are various reasons expressed by the experts to answer why someone smoking. According to the Levy each individual has different smoking habit and are usually tailored to the goals they are smoking. The opinion is supported by Smet stating that a person smokes because of the social cultural factors such as cultural habits, social class, level of education, and the prestige.

Surveillance against the Association by teenage parents and schools will give maximum results in addressing the behavior of smoking in teenagers. Parents should supervise children's play environments and how my peers. Because, when the teenager was dependent on a group of peers, adolescents need to be accepted and recognized by the group. When making friends with a group of people who smoke, then the child will easily smoke either. According to Kurt Lewin in the Efri (2007, p. 87), that the smoking behavior is a function of the environment and the individual. That is, besides the smoking behavior-induced factors from inside also due to environmental factors. In addition, according to Mu'tadin (2002, p. 7) Cause factor behavior of smoking on children is the influence of parents, peers, personality factors, and advertising.

The influence of peers on the attitudes, interests, conversation, appearance and behavior of the greater influence of the elderly. For example, when members of the Group try smoking or talking dirty so children tend to follow it regardless of their own feelings and consequences thereof (Hurlock, 1999). This can be explained by the concept of conformity which occurs in children. Further Santrock (1998) says that the conformity occurs when children are adopting the attitude or behavior of friends were due to pressure either directly or not. The Children succumb to the pressure of the group directly because request directly to follow what has been created by the group.

\section{Conclusion}

An environment where teenagers socialize also has a major role in the smoking behavior among adolescents and children. Social or environmental factors, is a place where one's character a lot of established, either from family, neighbors, friends or his intercourse. Socializing is the main way in children and teenagers to find their 
identity. By looking at what others have done and sometimes try to imitate what others have done. So if in the immediate surroundings there is the habit of smoking, then a teenager who was in the neighborhood tend to behave to smoke as well. Troubleshooting for the smoking behavior among adolescents and children by way of early prevention, starting from the smallest neighborhood families

\section{Conflict of interest statement}

Authors declare that they have no conflict of interest.

\section{References}

Abidin. 2009. Faktor-Faktor Penyebab Kecanduan Merokok (online) http://abidinblog.blogspot.com. Diakses tanggal 10 Desember 2010.

Aritonang, M.E.R. 1997. Fenomena Wanita Merokok. Skripsi Tidak Diterbitkan. Yogyakarta: Universitas Gajah Mada.

Aritonang, MER. 1997. Fenomena Wanita Merokok. Skripsi. Tidak diterbitkan. Yogyakarta: Fakultas Psikologi UGMBerry, JW., Pootinga, YPEH.,

Atkinson, Rita L; Atkinson, Richard C.; Smith, Edward E. dan Bem, Darly J. Tanpa tahun. Pengantar Psikologi. Batam: Interaksara.

Bekti. 2010. Lindungi Remaja Bahaya Rokok. (online) http://medicastore.com. Diakses tanggal 10 Desember 2010./

Brigham, C.J., 1991. Social Psychology. Boston: Harper Collins Publisher, Inc.Cahyani, B. 1995.

Chaplin, J.P. 2005. Kamus Lengkap Psikologi. Jakarta. Rajawali Pers.

Christanto, A. 2005. Merokok: Antara Ya dan Tidak (Suatu Kajian Praktis Filsafat Ilmu), (online), (http://www.mailarchive.com/dokter@yahoogroups.com/msg0035.html, diakses 5 Oktober 2010).

Daf Brigham C.J. (1991). Social psychology. Boston: Harper Collins Publisher

Davidson, G.C \& Neale, J.M., 1990. Abnormal Psychology. New York:John Willey \& Sons.Durkin, K. 1995. Developmental Social Psychology From Infancy to Old Age. Cambrigde: Blackwell Publisher.

Davison, Gerald C.; Neale, John M. and Kring, Ann M. 2006. Psikologi Abnormal (Edisi ke-9). Jakarta: PT. RajaGrafindo Persada.

Ellickson, Ph.D, Phyllis L.; Orlando, Ph.D, Maria; Tucker, Ph.D, Joan S. and Klein MS, David J. 2004.
From Adolescence to Young Adulthood: Racial/ Ethnic Disparities in Smoking. American Journal of Public Health, 94(2): 293-299.

Enggarsasi, Aries. 2008. Perbedaan Tingkat Stres Antara Mahasiswa Berkepribadian Extrovert Dan Introvert Dalam Pengerjaan Skripsi. Skripsi Tidak Diterbitkan. Malang: Universitas Negeri Malang.

Fink, George. 2007. Encyclopedia of Stress Vol II. 2nd ed. San Diego: Academic Press.

Gatchel, R.J.. 1989. An Introdunction to Health Psychology. New York: Mc Graw-Hill Book Company.

Gsianturi. 2003. Merokok dan Kesehatan! (online) http://www.gizi.net. Diakses tanggal 10 Desember 2010.

Gullotta, Thomas P. \& Adams, Gerald R. 2005. Handbook of Adolescent Behavioral Problems: Evidence-Based Approaches to Prevention and Treatment. New York: Springer Science.

Hanurawan, F. 2008. Ilmu Sosial dan Budaya Dasar (Bahan Bacaan). Malang: Universitas Negeri Malang.

Harian Republika. 30 Oktober 1998. Republika. 1998. Dibanding AIDS dan TBC, Merokok Lebih Banyak Mematikan. Harian Republika. 30 November 1998.

Harlianti, T.T. 1988. Hubungan antara Pemenuhan Kasih Sayang Orang Tua dan Pengaruh Lingkungan Merokok Teman Sebaya dengan Tingkah Laku Merokok Remaja SMP. Skripsi. Tidak diterbitkan. Yogyakarta: Fakultas Psikologi

Haryono. 2007. Hubungan Antara Ketergantungan Merokok Dengan Percaya Diri. [online] tersedia di http://www.infoskripsi.com/Artikel-Penelitian/Keter gantungan-Merokok.html pada pada: 7 mei 2009, 06.30.

Hurlock, B.Elizabeth. 1999. Psikologi Perkembangan: Suatu Pendekatan Sepanjang Rentang Kehidupan. Terjemahan oleh Istidawanti \& Soedjarwo. Jakarta: Erlangga.

Karch, M.D., Steven B. 1998. Drug Abuse Handbook. New York: CRC Press.

Kemala N, Indri. (2007). Perilaku Merokok pada Remaja. Semarang: Digital USU.

Komalasari, D \& Helmi, A.F (2000). Faktor-Faktor Penyebab Perilaku Merokok Pada Remaja.[online] tersedia di http://avin.staff.ugm.ac.id/data/jurnal/ perilakumerokok_avin.pdf pada: 7 mei 2009, 06.30.

Komalasari, Dian \& Helmi, Avin Fadilla. 2000. FaktorFaktor Penyebab Perilaku Merokok Pada Remaja. Jurnal Psikologi, 28: 37-47.

Komalasari, Dian Avin Fadilla. 2010. Faktor-Faktor 
Penyebab Perilaku Merokok pada Remaja. (online) http:// avin.staff.ugm.ac.id/ data/jurnal/perilakumerokok_avin.pdf. Diakses tanggal 10 Desember 2010.

Magdalena, Maria. 2010. Proses Sosialisasi. (online) http://www.sekolahrumah.com. Diakses tanggal 15 Desember 2010.

Mutoif, Dorin. 2009. Teori Sosial Kognitif. (online) http://dmutoif.blogspot.com. Diakses tanggal 15 Desember 2010.

Nainggolan, R.A. 2001. Anda Mau Berhenti Merokok? Pasti Berhasil. Bandung: Indonesia Publishing House.

New York: Houghton Mifflin Company Republika. 1998. Lebih Tiga Juta Meninggal karena Tembakau dalam Setahun.

New York: McGraw-Hill Book Co Kendal, P.C \& Hammen, C. 1998. Abnormal Psychology: Understanding Human Problems.

Patterson, T.L.1993. Helath and Human Behavior.

Pikiran Rakyat. (2009). Kebiasaan Merokok Dalam Tinjauan Kesehatan Jiwa. 10 Mei 2009

Poerwadarminta. (1995) Kamus Umum Bahasa Indonesia. Jakarta: Balai Pustaka
Republika. (1988). Lebih Dari Tiga Juta Meninggal Karena Tembakau dalam Setahun. 30 oktober 1988

Rita L. Atkinson, dkk. (1983). Pengantar Psikologi, edisi kedelapan, Jakarta: PT. Erlangga,

Santrock, J. W. 2007. Perkembangan Anak Jilid 1. Edisi Kesebelas. Erlangga. Jakarta

Segall, M.H., Dasen, P.R., 1992.Cross-cultural Psychology: Research \& Applications. Cambridge: Cambridge PressUniversity.

Smet, B (1994). Psikologi Kesehatan. Semarang: PT gramedia

Smet, B. 1994. Psikologi Kesehatan. Jakarta: PT Gramedia Widiasarana Indonesia.

Suhariyono, A. 1993. Intensitas Merokok dan Kecenderungan Memilih Tipe Strategi Menghadapi Masalah pada siswa SMTA di Yogyakarta. Skripsi. Tidak diterbitkan.

Yogyakarta: Fakultas Psikologi UGM Theodorus. 1994. Ciri Perokok di Kalangan Mahasiswa/1 Universitas Sriwijaya. Jurnal JEN. No. 3, 19-24.

Yulianti, Fitri. 2010. Anak Harus Tahu Bahaya Merokok. (online) http://bebasrokok.wordpress.com. Diakses tanggal 10 Desember 2010.

\section{How to cite this article:}

Kes, M. M., 2017. Trend of smoking behavior and the social impact on adolescents at Makassar in Indonesia. Int. J. Curr. Res. Biosci. Plant Biol. 4(3), 33-40. doi: https://doi.org/10.20546/ijcrbp.2017.403.004 